\title{
Community Mobilization and Awareness Creation for the Management of Enset Xanthomonas Wilt (EXW): The Case of Gerino Enset Tekil Kebele Administration, Gurage Zone, Southern Ethiopia
}

\author{
Zerihun Yemataw $^{1 *}$, Awole Zeberga ${ }^{2}$, Sadik Muzemil1, Fikre Handoro ${ }^{3}$, Mikias Yeshitla ${ }^{4}$ \\ ${ }^{1}$ Southern Agricultural Research Institute, Areka Agricultural Research Center, Areka, Ethiopia \\ ${ }^{2}$ Hawassa University, Hawassa, Ethiopia \\ ${ }^{3}$ Southern Agricultural Research Institute, Hawassa Agricultural Research Center, Hawassa, Ethiopia \\ ${ }^{4}$ International Potato Center, Bahir Dar, Ethiopia \\ Email: *yemataw.zerihun@yahoo.com
}

How to cite this paper: Yemataw, Z., Zeberga, A., Muzemil, S., Handoro, F. and Yeshitla, M. (2016) Community Mobilization and Awareness Creation for the Management of Enset Xanthomonas Wilt (EXW): The Case of Gerino Enset Tekil Kebele Administration, Gurage Zone, Southern Ethiopia. American Journal of Plant Sciences, 7, 17651781.

http://dx.doi.org/10.4236/ajps.2016.713165

Received: July 2, 2016

Accepted: September 13, 2016

Published: September 16, 2016

Copyright $\odot 2016$ by authors and Scientific Research Publishing Inc. This work is licensed under the Creative Commons Attribution International License (CC BY 4.0).

http://creativecommons.org/licenses/by/4.0/

(c) †) Open Access

\section{Abstract}

Enset bacterial wilt (EXW) caused by Xanthomonas campestris pv. musacearum is the major constraint in enset-based farming system. The opportunity to provide integrated EXW management options has opened a new vista and is enhanced by wellinformed communities who are aware of the management approach available to them. We hypothesized that differential success in EXW control is mainly due to approach used in the EXW control. It is the responsibility of the research institute to adequately inform these communities via a combination of community mobilization and awareness creation. This paper therefore assessed the importance of stake holders' mobilization and awareness creation for the promotion of technologies for EXW control in Ethiopia among 2010-2012. Individual interviews and direct on-farm participatory monitoring and observation with 60 farm households, key informant interviews, relevant secondary data, literature and inter-personal data were collected from unpublished progress report from National Enset Research Project, elderly people and senior experts. Results showed that about $25.6 \%$ of farmers' field was infected by the disease in 2007 and the level reached 54.5\% in 2010. End line assessment has shown that the disease prevalence declined to 10 percent in 2013. Disease incidence has shown that the intensity was highest in 2010; that is on average more than 17 enset were infected by the disease and shown significant decline in 2013 to about 1 infected enset on the infected fields. The intervention brought about promising step-ups in controlling the devastation by EXW. This intervention demonstrated that the disease impact can be minimized to a significant level if community 
mobilization and awareness creation with other local formal and informal institutions go hand in hand to out scale the experience to a wider range of enset farming communities.

\section{Keywords}

Awareness Creation, Community Mobilization, Enset, Enset Xanthomonas Wilt, Integrated Management, Gurage Zone

\section{Introduction}

Enset is a multipurpose crop with all plant parts being utilized for human food, animal forage, medicinal or ornamental uses [1]. It has high significance in day-to-day life of the peasant households cultivating this crop as staple food [2] [3]. Despite its importance, the crop has been quickly losing ground as a dependable crop due to several biotic and abiotic factors. Bacterial wilt [4], bacterial corm rot [3] [5], and bacterial sheath rot [6] are the known bacterial diseases identified and reported so far. Enset bacterial wilt caused by Xanthomonas campestris pv. musacearum, which was first reported and described by [4], was the major constraint that is economically important and threatening enset-based farming system [7]. A natural epidemic of the disease was reported from the banana cv. Ducasse hybrid in Kaffa province of southwestern part of Ethiopia [8].

Enset bacterial wilt is widely distributed in many enset growing regions of the country and affects the crop at all stages [9] covering high, mid and lower latitude areas of the Central, Southern and Southwestern enset growing regions of the country [10]. Area allocated to enset production is declining from time to time due to bacterial wilt attack and many farmers started replacing enset fields with other crops [10] [11]. The situation aggravated the problems of food shortage in the densely populated areas of southern Ethiopia.

Enset is an orphan commodity and less investigated and consequently, information on its disease management and improvement is very limited. In earlier works, enset cultivars collected from the Sidama, Guragie, Kembata/Tembaro and Hadiya Zones were screened for resistance/tolerance to X cm at the Awassa Agricultural Research Center and reported that the cultivars showed varying degree of tolerance to the disease [12] [13]. Cultivars such as Mazia, Ado, Lemat and Badedet have been further evaluated onfarm, with farmers' participation, and found to be tolerant to the disease [13].

Over the last 10 years, a lot of efforts have been devoted to controlling EXW in Ethiopia. Management package used and promoted country wide included; disinfecting farming and processing tools, uprooting and burning the infected enset plants, keeping fields and surrounding areas free of weeds and volunteer plants (alternative hosts), exposing the soil during dry season prior to planting, proper spacing, avoiding overflow of water from infested to uninfected fields, controlling porcupine, mole rat, and other domestic animals from browsing, use of clean planting materials (suckers or corms), strict control of the movement of planting material from one area to other (developing 
local quarantine system), rotation of crops, and use of resistant or tolerant landraces. It was suggested that proper and stable use of both cultural practice and sanitary control measures helps to minimize pathogen spread [3] [7]. According to [11] about 71\% of the farmers reported that careful application of the above cultural practices and sanitary control measures helps to control EXW disease. [14] also pointed out that early detection and destruction of the diseased plants as key steps in preventing disease spread.

The research institutes and MOA tried to promote the EXW management throughout the country. It would seem that awareness about the availability of the EXW management methodology available at these institutions as well as others spread around enset producing zones is not enough, necessitating efforts at raising awareness and community mobilization.

"Awareness-raising" is a means of alerting specific groups and the public in general to the existence of EXW and the need to address it. It is a two way street, fostering communication and information exchange in order to improve mutual understanding, whilst mobilizing communities and the wider society to bring about the necessary change in attitudes and behavior [15].

Community mobilization, on the other hand, is a capacity-building process through which community members, groups, or organizations plan carry out and evaluate activities on a participatory and sustained basis to improve their livelihoods either on their own initiative or stimulated by other [16].

EXW control technologies promoted using a mix of top-down extension and participatory approaches. Mixed levels of success in controlling EXW have been reported in various enset producing areas of Ethiopia. In this study we hypothesized that the partial success in EXW control was mainly due to varying levels of mobilization of stakeholder partnerships, to exploit stakeholders' synergies at local and national levels. The study was conducted in 2012/2013 to enhance the implementation of integrated disease management of EXW using awareness creation and community mobilization. The specific objectives were to 1) enhance farmers and agricultural experts with the available improved EXW management technologies, 2) demonstrate proven EXW control measures through awareness creation and community mobilization.

\section{Materials and Methods}

\subsection{Description of the Research Area}

The SNNPR is one of the regions in Ethiopia. It is located in south and southwestern part Ethiopia, $4.43^{\circ} \mathrm{N}-8.58^{\circ} \mathrm{N}$ latitude and $34.88^{\circ} \mathrm{E}-3914^{\circ} \mathrm{E}$ bordering Kenya to the south and South Sudan to the west and southwest, the Ethiopian region of Gambela to the northwest, and the Ethiopian region of Oromia to the north and east (Figure 1). The region has a total area of 110,931.9 square kilometers lying within elevations of 378 to 4207 meters above sea level [17]. The annual temperature is less than $10^{\circ} \mathrm{C}$ in the extreme highlands to over $27^{\circ} \mathrm{C}$ in the lowlands of the south. The regions are sub divided in to zones, which are organized in to weredas/districts. The zones are named based on the name of the dominant ethnic group for that specific location. The Regions are sub- 


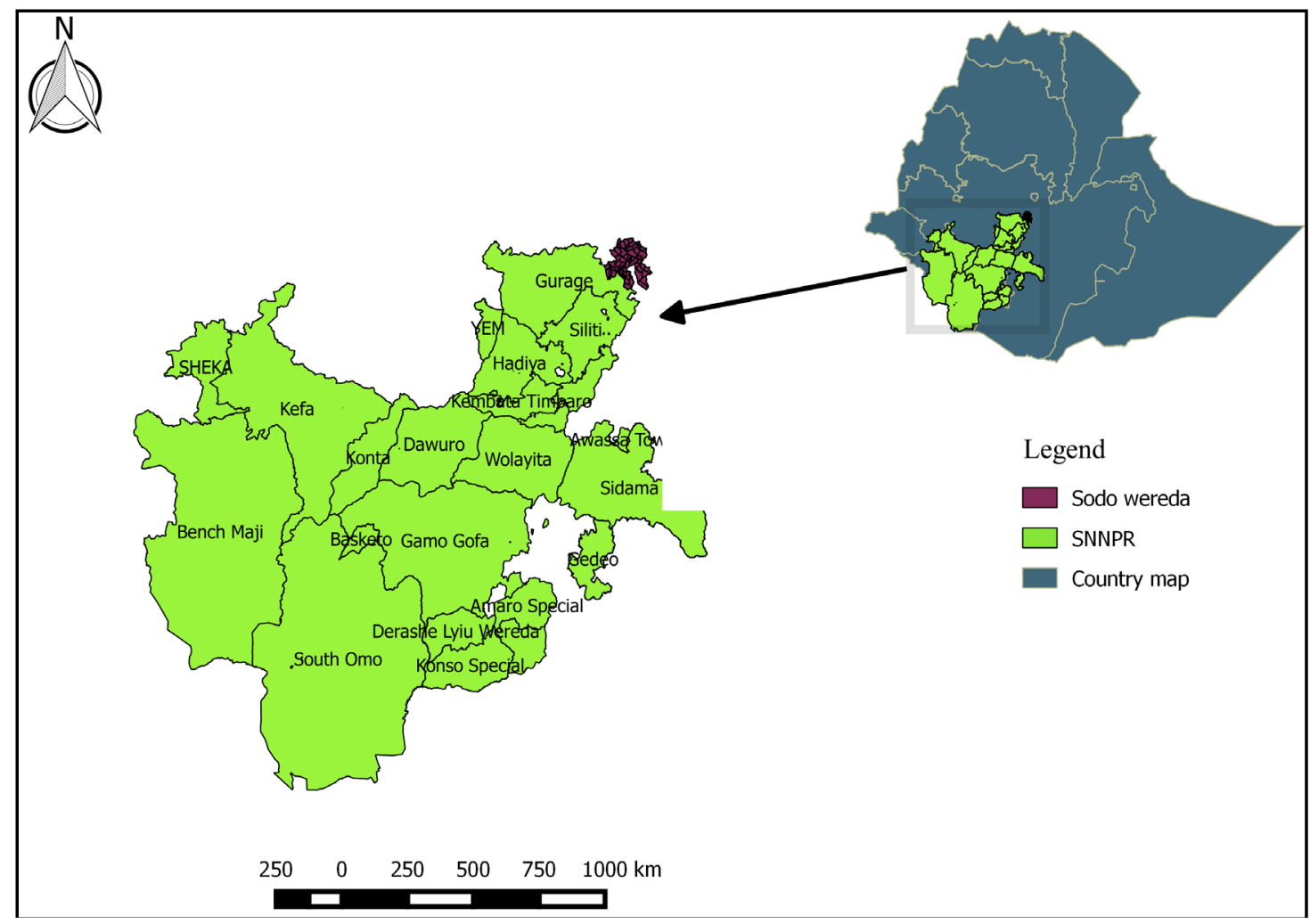

Figure 1. Map and position of the study region in Ethiopia. Detail district/woreda map of the study region.

divided into Zones, which are organized into Weredas. Within Weredas, Kebele Adminstrations (KAs) are the smallest administrative units.

Sodo wereda is located in Gurage zone in Southern Nations, Nationalities and Peoples Region (SNNPR) of Ethiopia. It is one of the twelve weredas of Gurage zone. It is located at $8^{\circ} 265.6^{\prime \prime} 76^{\prime} \mathrm{N}$ and $38^{\circ} 36^{\prime \prime} 43.56^{\prime} \mathrm{E}$ and at an elevation ranging from 1740 to 2900 meters above sea level. The district is bordered on the south by Meskanena and Mareko district and on the west, north and east by the Oromia Region. The administrative center of the district is Buee Town. The annual rainfall varies from $900-2000 \mathrm{~mm}$ and the annual average minimum and maximum temperature varies from $15^{\circ} \mathrm{C}$ to $25^{\circ} \mathrm{C}$ (Figure 1). The selection was based on the interest of the donor organization.

\subsection{Approaches and Steps Followed}

Step 1 Stakeholders planning meeting: Potential stakeholders were identified and planning meeting was held with governmental and other formal and informal institutions at district level in Gurage province of Southern Ethiopia. The meeting encompasses district and local government authorities, Southern Agricultural Research Institute (SARI) and Ethiopian Institute of Agricultural Research (EIAR) top management officials, community leaders, religious elders, school directors, extension staffs and model farmers. Participants discussed about the problem and its potential impact and set common objective and shares respective roles and responsibilities. 
Step 2 Base line survey: Discussions were made with experts working in agriculture and rural development offices to select the representative study sites within the wereda. For this purpose the smallest administrative unit in the district Kebele Administrative (KA) was used. Eventually, following the discussion and based on the available secondary data, three KA were selected for interviews. Preliminary field visit was made prior to the actual field work in the selected KA in order to familiarize with the area and development agents working there.

The data collection was conducted mainly through: 1) individual interviews and direct on-farm participatory monitoring and observation, 2) group discussion, 3) key informant interview and 4) secondary data and literature survey.

A farm that contained at least one plant with visible EXW symptom was regarded as infected. Disease incidence was calculated as the number of infected farm divided by the total number of assessed farms.

\subsection{Individual Interviews and Direct on-Farm Participatory Monitoring and Observation}

Semi-structured interviews were designed and data collected with the head of the household or the person responsible for maintenance of the enset plantation. Sixty farmers were interviewed and directly monitored on farms, Over the selected three Kebele Administrations (KA) (the lowest government authority unit) in order to assess the farmers' knowledge on EXW, and the status of EXW before the intervention Figure 2(a).

\subsection{Group Discussion}

In addition to face-to-face interviews, two focus group discussions were carried out to complement the information obtained from individual farmer. Seven farmers from each KA were identified to conduct in-depth interview and follow-up on issues of interest raised during individual interviews (Figure 2(b)).

\subsection{Key Informant Interviews}

In order to assess the knowledge of farmers' in each KA: key informants up to five per KA, community leaders, local administrations, and MOA (Ministry of Agriculture), and other members in the KA were interviewed (Figure 2(c)).

\subsection{Secondary Data and Literature Survey}

Southern Agricultural Research Institute progress report was visited for secondary data and personal communication and discussion with elderly people and senior experts in line with knowledge of farmers on EXW. Literatures on EXW management were reviewed from published and unpublished sources and reports.

Step 3 Awareness creation training: Farmers' indigenous knowledge about the disease symptoms, transmission and control measures was enhanced through subsequent training at various levels and on station demonstration. Subsequent training on currently available and proven improved enset production and bacterial wilt management 


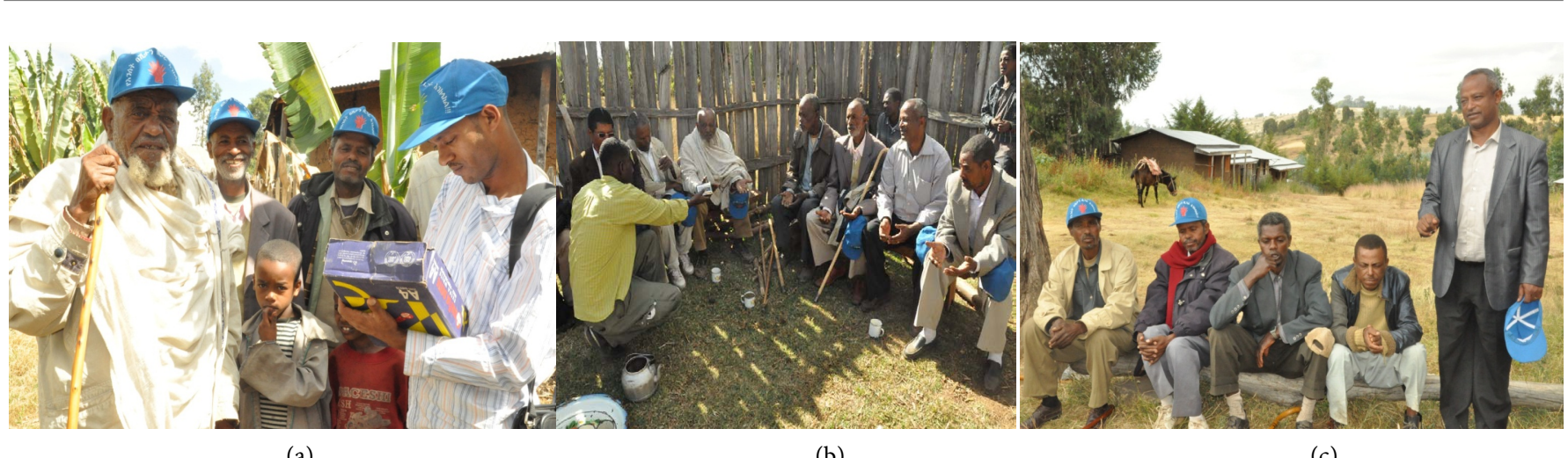

(a)

(b)

(c)

Figure 2. (a) Individual interview, group discussion (b) and key informant discussion (c).

technologies were given to farmers, development agents, leader of local institutions and local government authorities. Four training were given in Kebele Adminstration and district levels including a field demonstration and a practical session at Areka Agricultural Research center (ARC) (Table 1 and Figure 3). The first three trainings focused on theoretical description of enset bacterial wilt management options \& improved enset production technologies. The last session was a practical demonstration of sanitary control measures and improved enset production and post-harvest technologies.

Leaflets, posters and manuals describing improved enset production technologies and EXW management options was prepared and distributed to facilitate better diffusion of information to the neighboring districts.

The selection of the trainee was carried out jointly by the district agricultural office, Research Institute and KA. During selection the team considered: 1) farmers having enset fields; 2) a farm that contained EXW infected plants. Those selections used a mixed method approach therefore allowed for the integration of two types of research methods into a single study enabling a deeper understanding of the questions posed in the training. Mixed methods is defined as "the class of research where the researcher mixes or combines quantitative and qualitative research techniques, methods, approaches, concepts or language into a single study" [18].

Step 4 Taskforce establishment: Task force at district level headed by district administrator and bureau of agriculture head as a secretary was established. The task force members vested the power to establish task force at Kebele Administration level and regularly meet and monitor the progress and facilitate activities to make a contribution towards the control of the disease. The Kebele Administration level task force headed by Kebele Administration chairman and comprises Kebele Administration government structures and other formal and informal institutions and model farmers. Government Institutions "development group" and 1 - 5 group "cells" (one leader and five followers) have given the assignment to lead, conduct and report all the activities undertaken during the community mobilization campaign. Members in the taskforce were given roles and responsibilities to implement, act individually and collectively in the implementation of the collective action. Feedback information based on the findings of this project shared and distributed to each enset growing zones during the workshop con- 
Table 1. Number and category of participants during the training.

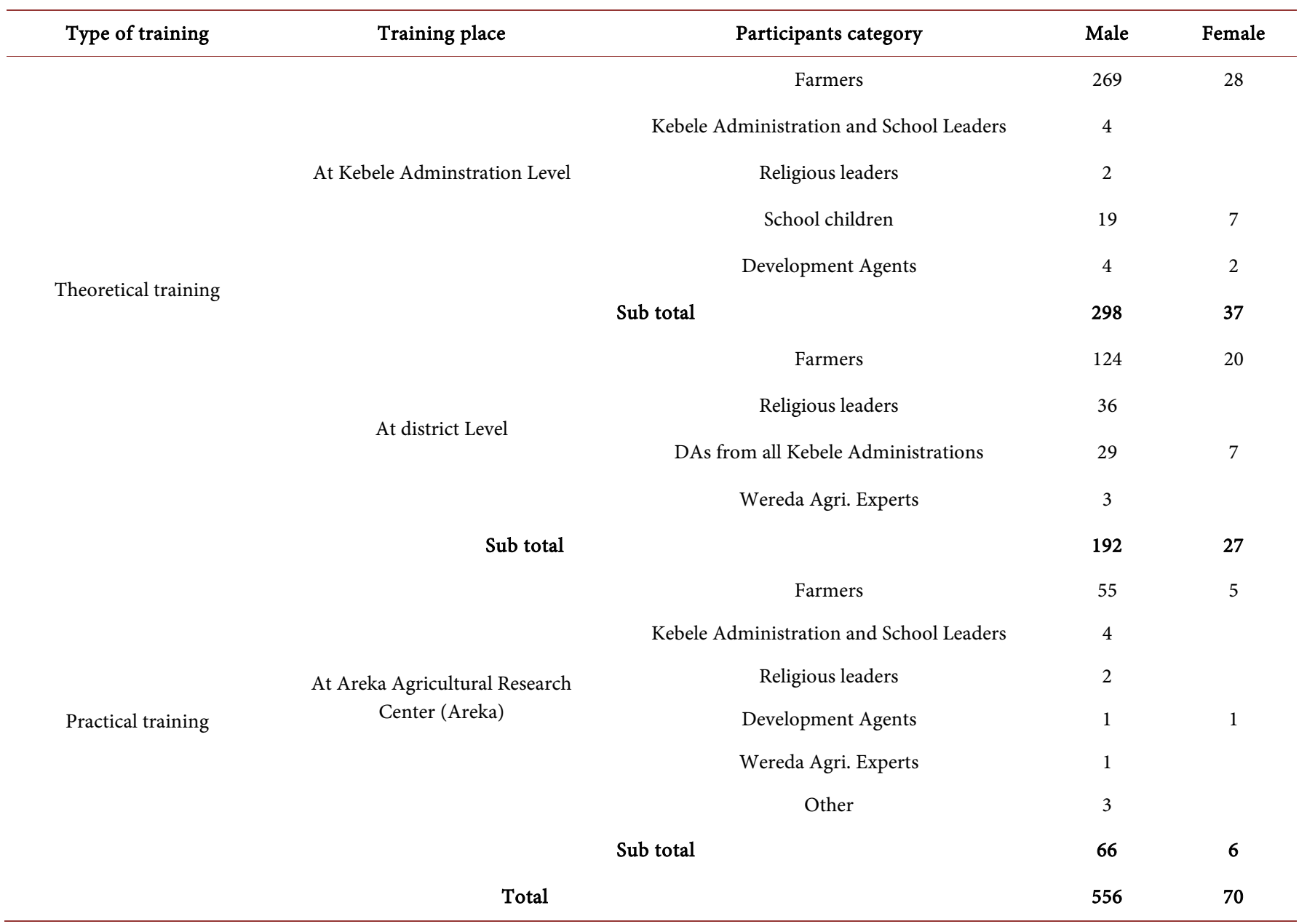

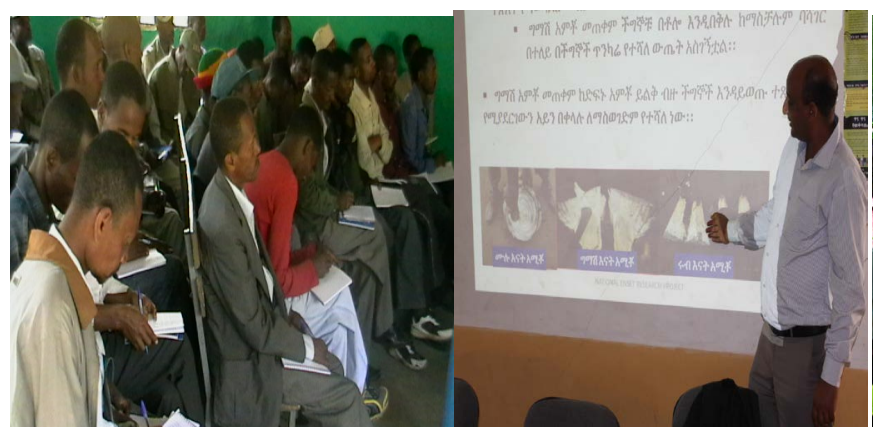

(a)

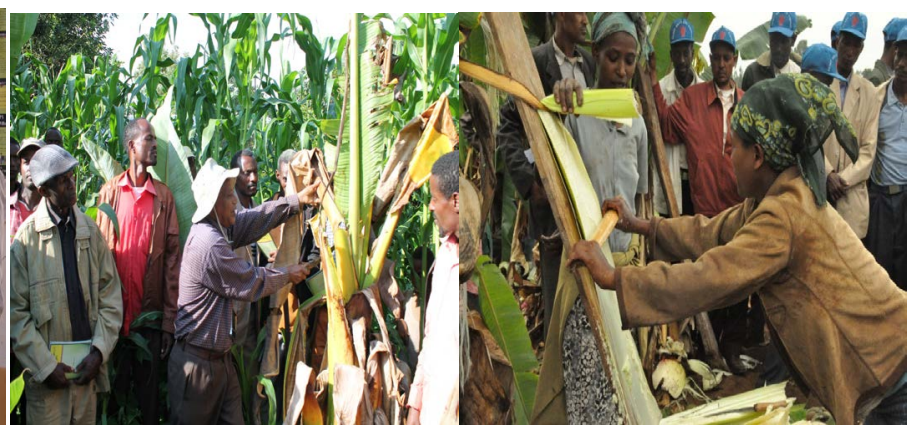

(b)

Figure 3. Awarness creation through theorotical (a) and practical training (b).

ducted at Wolkite town of Gurage province.

Step 5 Community mobilization: The researchers team from Awassa and Areka Agricultural Research Center developed draft by-lows and presented, commented and approved by the participants to govern the agreed up on actions during the course of community mobilization and campaign. The community in the respective locality dis- 
cusses and approved the by-laws to govern the agreed upon actions and associated penalties for a default.

Community mobilization was conducted followed by raising farmers' awareness about EXW cause, transmission, control and prevention means along with all other improved enset production and disease/pest management practices. A complain that lasts for one month was launched by the established task force and all community members were actively participated. Development group" (Limate budin') and 1 - 5 individuals (called cells) offered an opportunity to mobilize majority of the community members during the implementation of eradication campaign.

Step 6 Multiplication and distribution of recommended disease tolerant enset cultivar: Recently recommended disease tolerant cultivar Mazia, was multiplied at the target Kebele Administration and distributed to 265 farmers, 40 suckers for each and a total of 10,520 suckers were delivered. Farmers are advised to incorporate this cultivar into their diversity rather than replacing their existing cultivars. Informal discussion with received the cultivar confirmed that they plant the suckers on separate plots to evaluate and compare their performance with their diversity (Figure 4).

\subsection{End Line Survey}

End line survey was carried out using similar procedure applied for base line survey.

\subsection{Data Analysis}

Informal discussion with elderly farmers, and key informants were carried out to validate the information gathered from individual interviews. Collected survey data were subjected to descriptive statistics (frequencies, percentages, and average) using SPSS Ver. 20. Descriptive statistics were used and results expressed as frequencies and percentages in tables and figures.

\section{Result}

\subsection{Socio-Demographic Characteristics}

The socioeconomics and disease aspects of the target area based on the information gathered from 60 sample respondents during survey were analyzed and presented in
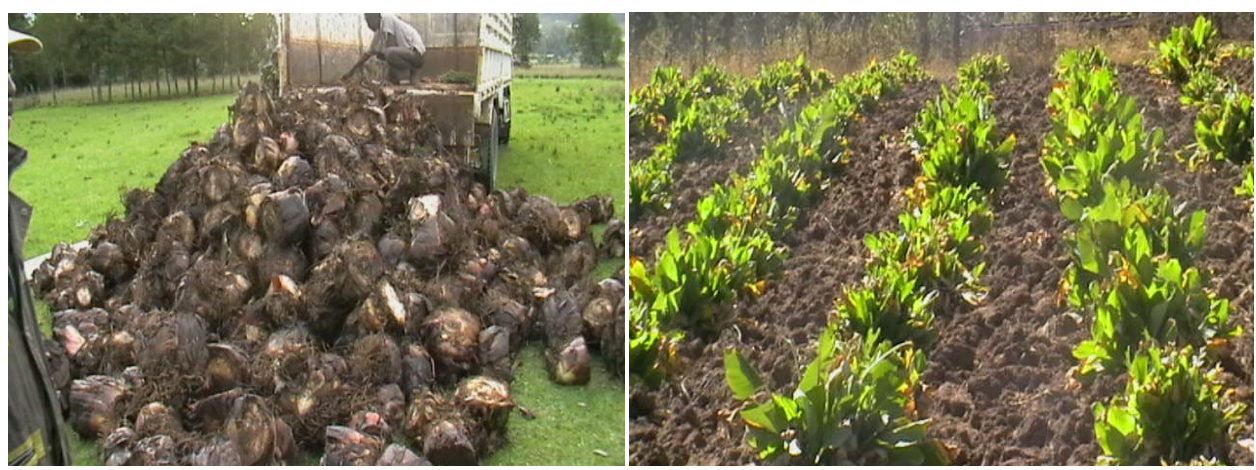

Figure 4. Multiplication of recommended disease tolerant maziye cultivar. 
this section (Table 2). According to the descriptive analysis 13.8 and 86.2 percent of the sample respondents were female and male headed households respectively. The average age of respondents in the district is about 48.9 years which is relatively higher than the average probably due to the tendency of younger household heads migrate to towns in search of better income that is common in Gurage community. Literacy level of the sample respondents has shown that 31.2 percent of the sample respondents were illiterate where as 68.8 percent accessed to either formal and/or informal education. On average sample respondents have family size of 6.2 out of which 3.3 and 2.9 are male and female members respectively. On average about 2.3 often elder family members live abroad that has implication on the family's labor supply that in turn has adverse impacts in the prevention and control of EXW. This result also suggests that most of the farmers are middle age people who are still active to make meaningful impact in agricultural production.

\subsection{Gender Role of Enset Production and Marketing}

Women take the lion shares in undertaking various activities in enset production and marketing (Table 3). They have more responsibility for the management and control of almost all activities. Therefore the development efforts targeted toward revitalization of enset production and productivity provides ample opportunities in maintaining gender balance.

Table 2. Socio-demographic characteristics of the intervention area.

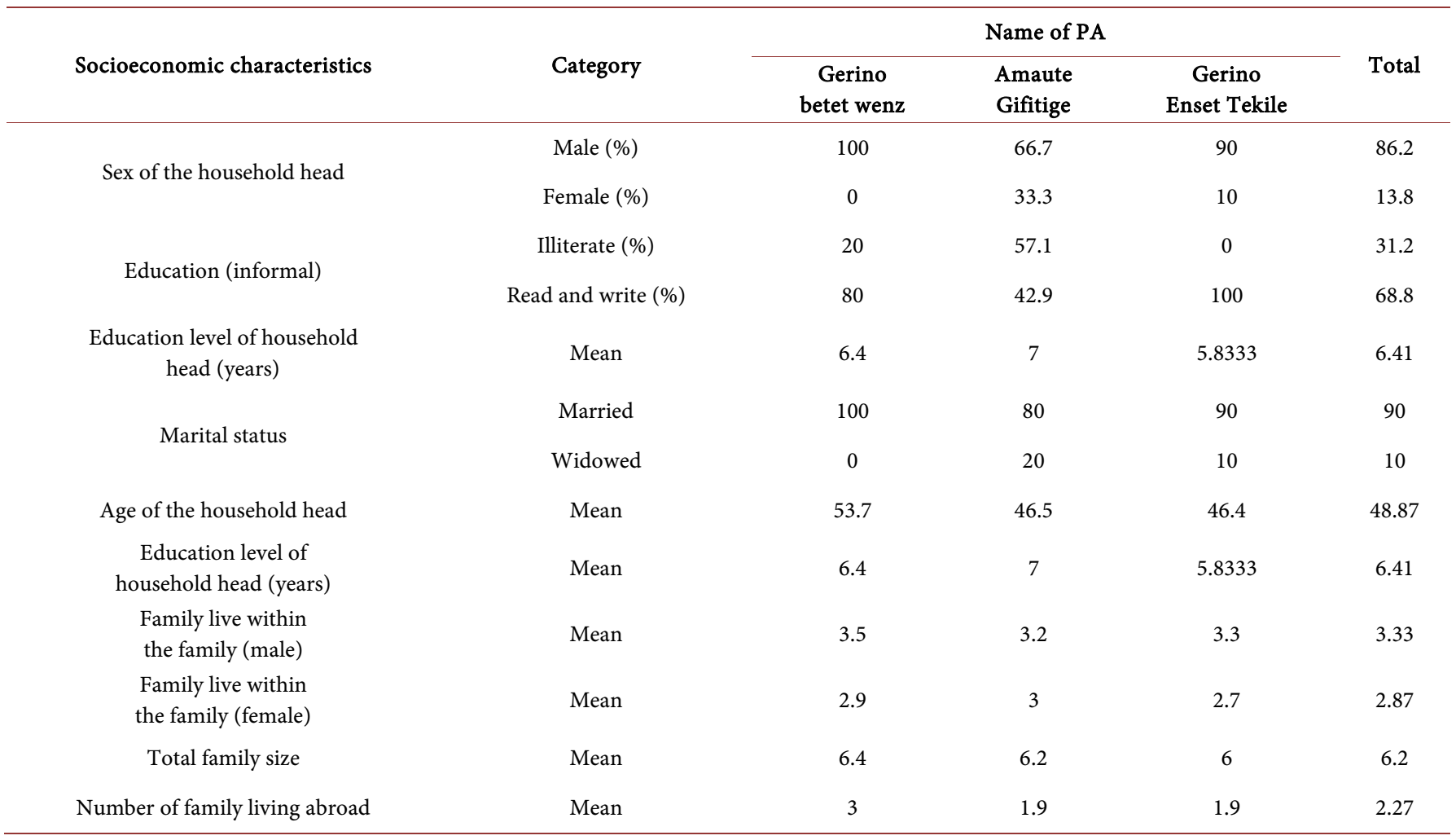


Table 3. Gender balance in enset production and management.

\begin{tabular}{cccc}
\hline Activities & Male & Female & Remark \\
\hline Enset production & $\mathrm{X}$ & $\mathrm{x}$ & \\
Enset bacterial Wilt management & $\mathrm{X}$ & $\mathrm{x}$ & \\
Enset Harvesting & $\mathrm{X}$ & $\mathrm{x}$ & \\
Enset processing & & $\mathrm{x}$ & \\
Enset product marketing & & $\mathrm{x}$ & \\
\hline
\end{tabular}

Source: computed from data.

\subsection{Prevalence of Enset Bacterial Wilt Disease}

Farmers in the three KA confirmed that EXW is the most important constraint to enset production. The presence of EXW in the three sampled KA showed ups and downs in the past six years. According to the information obtained from the sample respondents about 25.6 percent of farmers' field in Gerino enset tekile KA was infected by the disease in 2007 and this figure hits the highest point in 2010 that is 54.5 percent (Figure 5). This was the time when intervention demanded by the farmers and various partners were convinced to intervene, resource was allocated and partners shares roles and responsibilities. Researchers' team composed of different discipline had given the assignment to own and conduct in close collaboration with Bureau of Agriculture and local government authorities. End line assessment in 2012/2013 revealed that awareness creation and community mobilization play a significant role to reduce the number of infected fields to $10 \%$ (Figure 5).

\subsection{Incidence of EXW in the Target Districts}

Information obtained from the sample respondents in the past six years shown that disease incidence particularly in the intervention area was highest in 2010; that is more than 17 enset on average were infected by the disease in those infected fields and the figure has also shown significant decline in 2012/2013 to about 1 infected enset on the infected fields (Figure 6). This figure has implied that the intervention through awareness creation and community mobilization brought about promising step-ups in controlling EXW disease and also proven the disease can be controlled if enset farming communities and other partners strengthen partnership and work together toward a common goal.

\subsection{Farmers' Awareness on Modes of Transmission}

Farmers in the study areas have their own way of understanding on the mechanism of EXW disease transmission. Before awareness creation and community mobilization most respondents (30\% - 40\%) identified the principal means of EXW disease transmission from infected to healthy plants via contaminated farm tools, curse from God, insect and animals, even if a minority erroneously identified animal dung and wind transmission (Table 4). The proportion of farmers who believe the transmission is by 


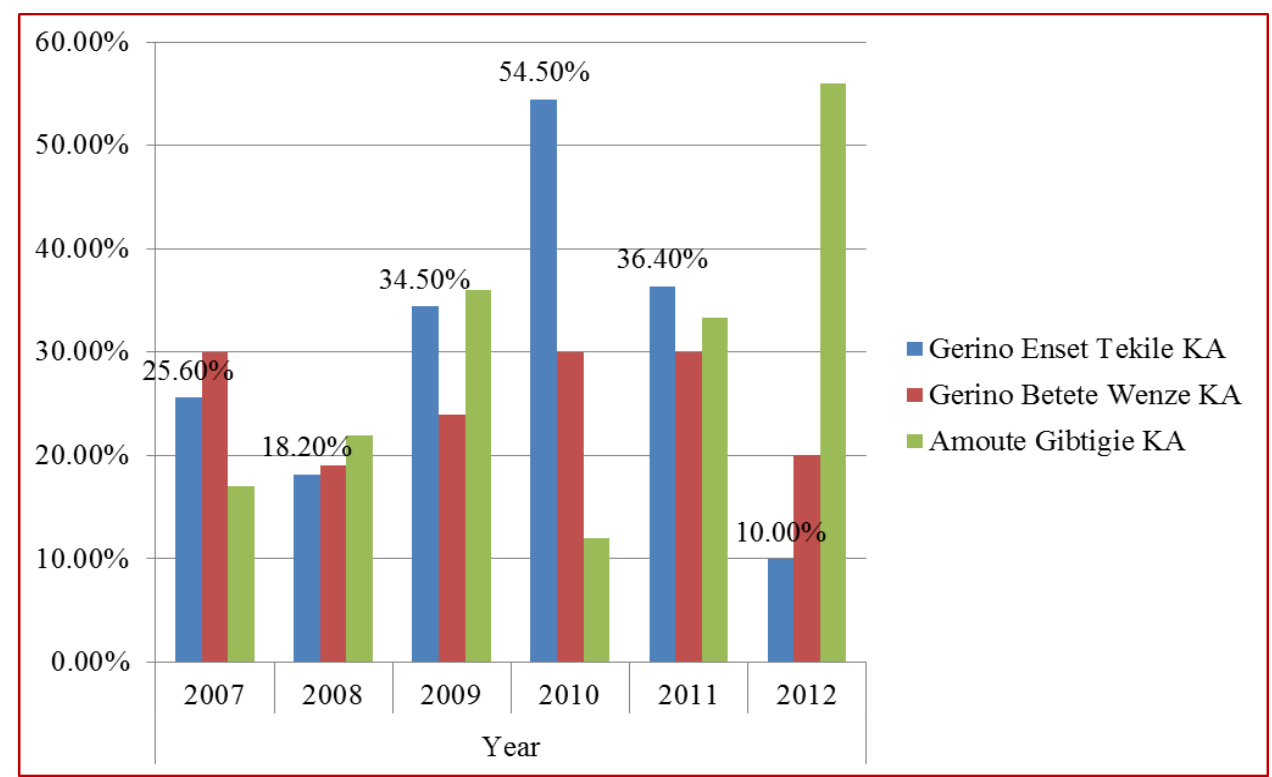

Figure 5. Prevalence of EXW in the target kebele administration from 2007 to 2012.

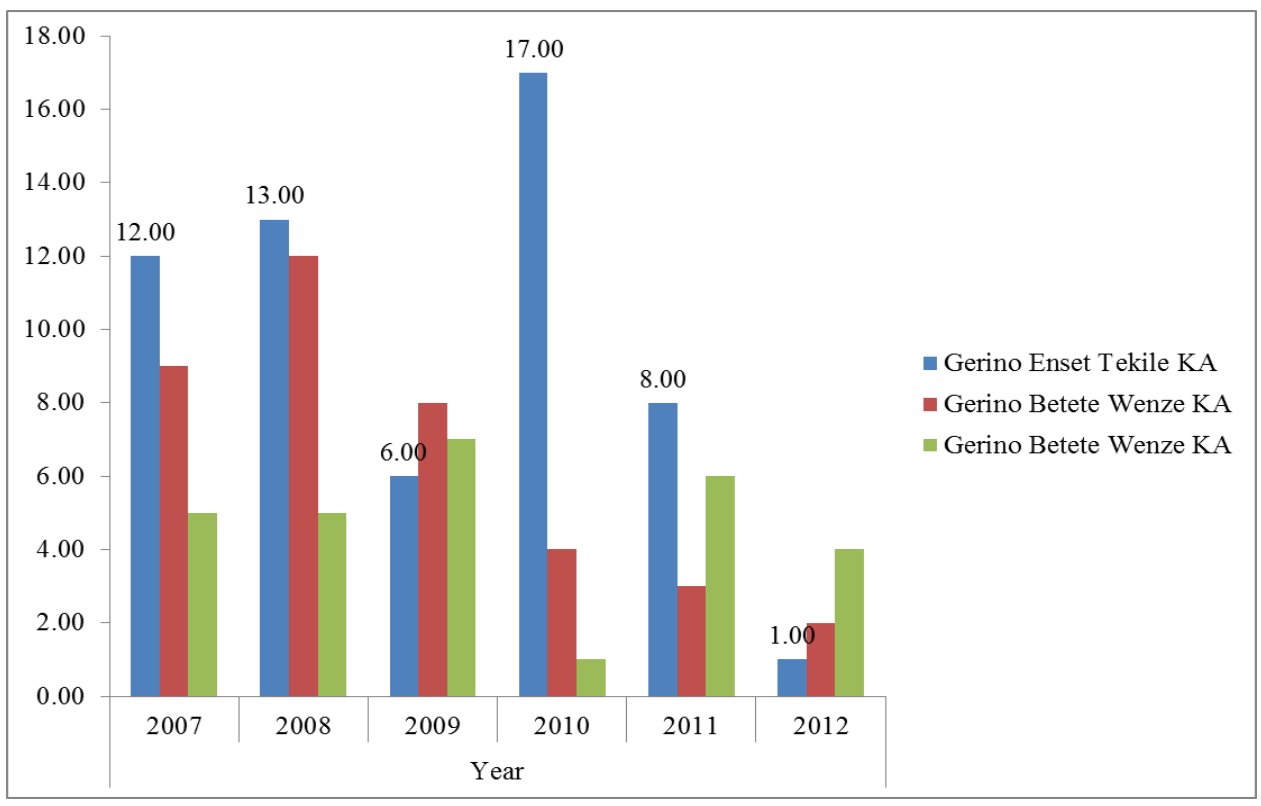

Figure 6. Average number of infected enset plant per farm.

curse from God is high for Gerino Enset Tekle KA (35.3\%) followed by Amawute Gifitige KA (30\%) (Table 4). The proportion of farmers who believe in different transmission mechanism are statistically significant $\left(\chi^{2}=30, \mathrm{P}<0.05\right)$.

The studies thus rigorously track and advance toward integrating farmers' indigen ous knowledge with the available demonstrated and proven Integrated EXW management options in controlling the disease through awareness creation and community mobilization (Table 4). From this investigation we can figure out that subsequent training given to farmers and extension workers enhance farmers' understanding about 
Table 4. Farmers' perceptions on symptoms, causal agents and mechanisms of transmission of EXW in central zones of southern Ethiopia.

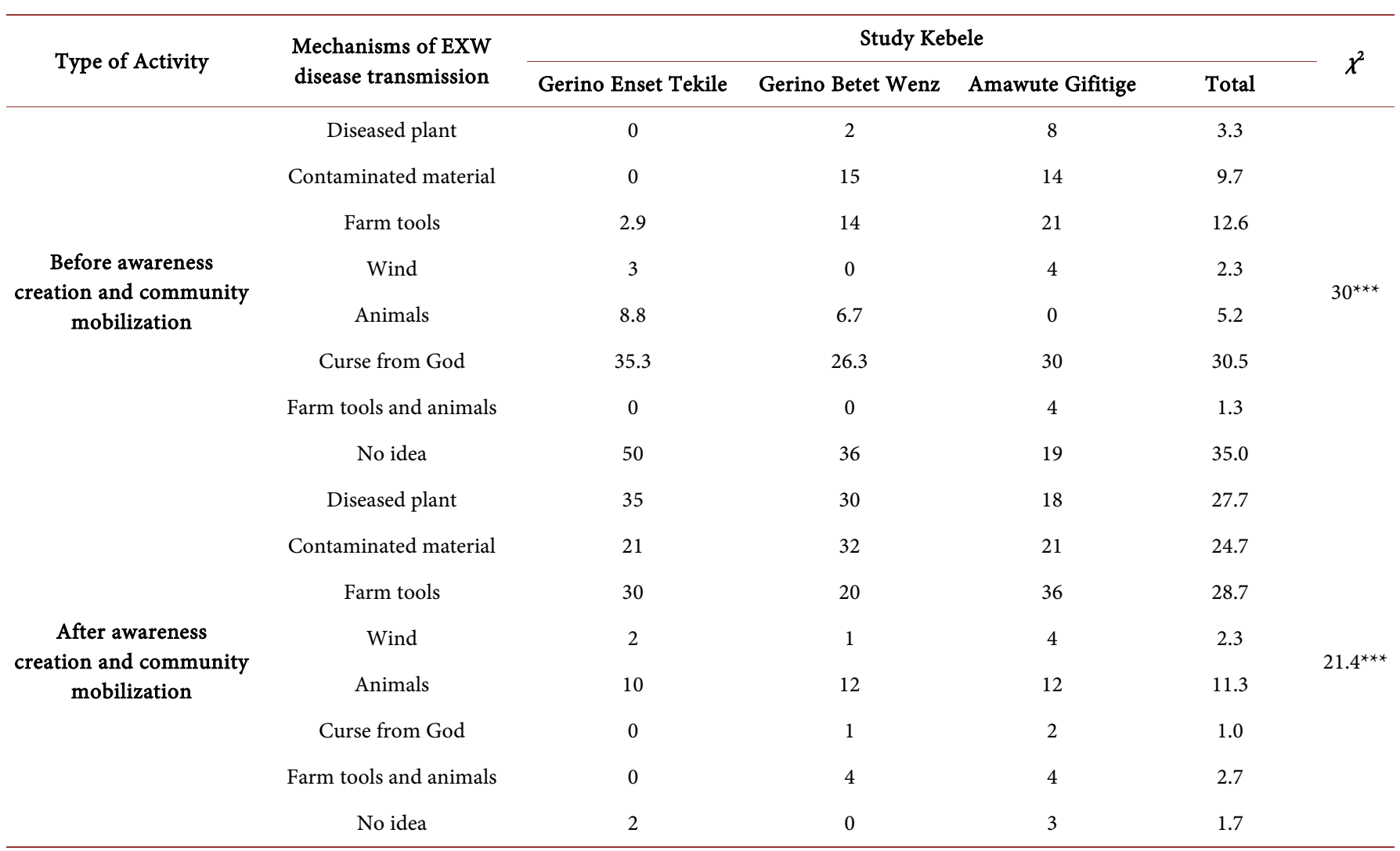

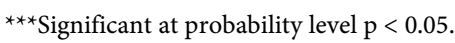

EXW means of transmission and ultimately disease prevention and control options to put forth in the course of the campaign against control of EXW.

\subsection{Farmers' Perception for the Management of the Disease}

Farmers' experience of disease prevention and control mechanism was assessed and found to be imperative and able to be well integrated in improved disease management options advocated to be implemented during the campaign. Farmers know how about the means of EXW prevention and control and they had been utilizing them for decades to combat the horrific impact caused by the disease on enset production and productivity that they consider it as mainstay of food and livelihood bases of millions of rural poor (Table 5).

\section{Discussion}

Farmers in the study area were characterized on their socio-demographics that might potential influence on disease distribution and impact on their livelihood. Age structures of family members probably enhance the prevalence and incidence of EXW. Significant number of their family members often elder members live abroad in search of better income which also reduces labor availability of peasant households whose major labor source is mainly family. 
Table 5. Presents farmers perception about prevention and control means of EXW.

\begin{tabular}{ccc}
\hline No. & Means of EXW Prevention & Means of EXW Control \\
\hline 1 & Fencing the enset field & Removing and burying infected plant \\
2 & Isolating own enset production and processing tools & Showering the infected enset with cattle urine \\
3 & Rouging and burring the infected plant & Keeping the field clean \\
4 & Own or trusted source of planting materials & Frequent visit of enset field \\
5 & Keeping the enset field clean & Raising suckers at own field \\
6 & Showering the infected enset with cattle & Crop rotation \\
7 & Smoking bones and plastics in the field & Baptizing with "Tsebel" \\
8 & Burning farming tools before use (borrowed) & \\
9 & Praying & \\
\hline
\end{tabular}

Various activities undertaken from the production point to the consumption end involves active participation of female household members and hence interventions related to improvement in the production and post-harvest handling of enset enhance maintaining gender balance.

The lives of millions of enset based farming communities are still threatened by the overwhelming disaster caused by the disease. Even the two neighboring KAs has also shown higher disease prevalence and incidence rate calling more efforts to put forth to learn from past experiences; integrate them with available and proven enset production and disease control options and scale out the achievements realized so far to wider range of enset farming communities. From farmers' points of view, EXW is considered either the primary or secondary enset disease in the three ethnic groups. Most farmers in both districts consider EXW is a constraint to enset production but it is a more serious production constraint in Hadiya. [19] reported that, EXW was the most important constraint in Hadiya, and Gurage, zones. [20] also confirmed the importance of EXW in West Shewa zone. However, [21] indicated that, the disease is the second important constraint that affects the production and productivity of enset in the Wolaita zone. A more comprehensive study [22] in southern region revealed that, on average $28.7 \%$ of enset stands was lost due to this disease in the surveyed zones of Southern Ethiopia .Hence designing programs for the improved management of EXW disease, it is important to recognize that farmers face multiple problems.

Our study has shown that the majority of farmers interviewed were able to properly identify an unhealthy plant and the mechanism of transmission from diseased plant to healthy plant via contaminated tools. [20] reported that 54\% of interviewed farmers in West Shewa zone believed that farming tool and browsing animals were the major factor for the transmission of the disease. Study on mechanical transmission and survival of bacterial wilt on enset [9] [13] also confirmed that use of contaminated knives used as a means of mechanism for the transmission of the disease.

When asked about different control measures, farmers in all participating zones were 
most familiar with sanitary practices and EXW control is largely based on this cultural practice but they not implemented properly. They were expecting chemical control from the concerned body. No chemical trial has been conducted so far and there is no information regarding the use of chemical as an option for the disease.

We understood that lack of adequate information on the biology and epidemiology of the pathogen was not well understood by farmers. Those information and perennial nature of the plant have affected the development of effective control measures. Our study showed that current practices to manage EXW diseases are largely ineffective and probably unsustainable. Better practices are already available, but farmers will not use them unless they have a better understanding of the problems they are facing.

Management options readily available to farmers include disinfecting farming and processing tools, uprooting and burning the infected enset plants, keeping fields and surrounding areas free of weeds and volunteer plants (alternative hosts), exposing the soil during dry season prior to planting, proper spacing, avoiding overflow of water from infested to uninfected fields, controlling porcupine, mole rat, and other domestic animals from browsing, use of clean planting materials (suckers or corms), strict control of the movement of planting material from one area to other (developing local quarantine system), rotation of crops, and use of resistant or tolerant landraces.

Farmers reply about the means of EXW prevention and control methods that worth mentioning and can be well integrated with improved disease management options. After assessing farmers' indigenous knowledge about disease management training was given which mainly focused on the available enset production and EXW management technologies and special emphasis was given for the need of awareness creation and community mobilization.

Despite the above mentioning awareness about the disease few farmers hesitate to eradicate the infected enset during the campaign and they justify this with food security status of their family that imply consideration of compensation scheme or other options in designing integrated EXW management to attain more practical achievements.

It was suggested that proper and stable use of both cultural practice and sanitary control measures helps to minimize pathogen spread [3] [7]. According to [11] about $71 \%$ of the farmers reported that careful application of the above cultural practices and sanitary control measures helps to control EXW disease. [14] also pointed out that early detection and destruction of the diseased plants as key steps in preventing disease spread.

In addition to management of EXW disease, awareness creation and training that combines traditional knowledge with disease identification, basic principles of epidemiology, and etiology of diseases and management strategies would be potentially useful. In our experience, cause of the disease and epidemiological principles are not understood by farmers. Therefore continues and uninterrupted public awareness creation program about the disease is mandatory. Farmer training on $X \mathrm{~cm}$ biology and how to control this disease is limited. Most organizations still use a top-down technology transfer approach based on providing recommendations. This could have negative im- 
plications when trying to promote integrated disease management. This technology requires horizontal and participatory methods of exchanging information and knowledge as suggested by [23]-[25] also confirmed that "The battle against $X \mathrm{~cm}$ wilt needs to be multi-faceted, requiring mobilization of all available human as well as financial resources. Everyone must be aware and be committed to make sound contribution towards the control of the disease. All stakeholders need to be given clear/concise and appropriate messages, stating what needs to be done by whom, how, where and when so that they in turn could play their roles effectively".

The need for political commitment at regional and federal level and mobilize the majorities using government institutional arrangement established so far at Kebele Administration level such as development group and 1 - 5 group (cells) along with other local formal and informal institutions praiseworthy during implementation of community mobilization and collective action approach promoted by various literatures being effective for EXW control.

\section{Conclusion}

This pilot intervention demonstrated that the disease impact can be minimized at least in the short term to a significant level. Community mobilization and awareness creation were the most effective in imparting knowledge about EXW control to farmers and mobilizing farmers to use the practices for EXW control. This may be attributed to the higher level of interaction between research, extension agents and farmers. A set of individual, organizational and institutional capacities that support these approaches in practice need to be developed for wider applicability. In summary, we propose a package for augmenting social capital and sustaining community participation in EXW management. At an individual level, competencies need strengthening in systems thinking, knowledge management, strategic planning, effective communication and networking. Organizations need to provide the performance and incentive systems that encourage inter-disciplinary teamwork, partnerships with other stake-holders, in a manner that foster mutual learning and effective knowledge management to promote change. However, the community mobilization and awareness creation was highly affected mainly by the dependency of farmers to the need of chemical for the control of EXW disease and other multiple factors. Continuous training should be given to the community to avoid this dependency syndrome and develop self-reliance in managing the disease from their fields. The involvement of local leaders in leading the community mobilization was also found vital in enhancing the community mobilization. Moreover, it was possible to realize that government attached local institutions has acceptance by farmers. The local social institutions could be used to enhance co-management of the disease through training farmers to build their capacity and bring attitudinal change towards community mobilization. In previous times, farmers used to accomplish development works through enforcement. Nevertheless, experiences using such approach have been unfruitful and unsustainable. In the current study, however, farmers were empowered to decide on the planning and implementation aspects of the community 
mobilization and this has relatively improved the success in EXW management.

\section{Acknowledgements}

We thank enset producing farmers in the pilot Wereda for their participation and sharing of ideas and knowledge on the different aspects of enset. We are also grateful for the development agents that assisted in the interviews and intervention with farmers. This study was supported by a grant from Southern Agricultural Research Institute and Ethiopian Institute Agricultural Research. The authors thank all persons who participated in the execution of the field work and in shaping up the manuscript. Special appreciation is due to the Areka and Awassa Agricultural Research Center for providing the vehicle during the survey work.

\section{References}

[1] Pijls, L.T.J., Timmer, A.A.M., Woldegebriel, Z. and West, C.E. (1995) Cultivation, Preparation and Consumption of Enset (Enset ventricosum (Welw.) Cheesman) in Ethiopia. Journal of the Science of Food and Agriculture, 67, 1-11. http://dx.doi.org/10.1002/jsfa.2740670102

[2] Beizuneh, T. (1984) Evaluation of Some Ensete ventricosum Cultivars for Food Yield with Emphasis on the Effect of Length of Fermentation on Carbohydrate and Calcium Content. Tropical Agriculture, 61, 111-116.

[3] Brandt, S.A., Spring, A., Hiesch, C., McCabe, S.T., Endale, T., et al. (1997) The Tree against Hunger. Enset-Based Agricultural Systems in Ethiopia. American Association for the Advancement of Science, with Awassa Agricultural Research Center, Kyota University Center for Africa Area Studies and University of Flora, Washington DC.

[4] Yirgou, D. and Bradbury, J.F. (1968) Bacterial Wilt of Enset (Enset ventricosum) Incited by Xanthomonas musacearum sp. n. Phytopathology, 58, 111-112.

[5] Quimio, A. and Tessera, M. (1996) Diseases of Enset. In: Abate, T., Hiebsch, C. and Brandt, S., Eds., Enset-Based Sustainable Agriculture in Ethiopia, Proceedings of the First International Workshop on Enset, IAR, Addis Ababa, 188-203.

[6] Quimio, A. (1992) Annual Report of the Plant Pathologist: July 17, 1991-July 16, 1992. Enset Team Support Project. Sidamo, Gamo-Goffa Peasant Agricultural Development Program. PADEP III. Awassa Research Center, IAR.

[7] Shank, R. and Chernet (1996) Mole Rats: Another Possible Mode of Spreading Enset Bacterial Wilt, Emergencies Unit for Ethiopia [UNDP-EUE] Development Programme, Addis Ababe, Ethiopia.

[8] Yirgou, D. and Bradbury, J.F. (1974) A Note Wilt of Banana Caused by the Enset Wilt Organism Xanthomonas musacearum. East African Agricultural and Forestry Journal, 40, 111 114.

[9] Ashagari, D. (1985) Studies on the Bacterial Wilt of Enset (Enset ventricosum) and Prospects for Its Control. Ethiopian Journal of Agricultural Science, 7, 1-14.

[10] Spring, A. (1996) Gender Issues and Farming Systems Research and Extension in Enset Agriculture in Ethiopia. In: Abate, T., et al., Eds., Enset-Based Sustainable Agriculture in Ethiopia, Institute of Agricultural Research, Addis Ababa.

[11] Tadesse, M., Kidist, B. and Gizachew, W.M. (2003) Enset Bacterial wilt Sanitary Control in Gurage Zone. Awassa, 53, 23. 
[12] Welde-Michael, G. (2000) Variations in Isolates of Enset Wilt Pathogen (Xanthomonas campestris pv. musacearum) and Reaction of Enset (Ensete ventricosum (Welw.) Clones to This Disease. M.Sc. Thesis, Alemaya University, Ethiopia, 61.

[13] Welde-Michael, G., Bobosha, K., Addis, T., Blomme, G., Mekonnen, S., et al. (2008) Evaluation of Enset Clones against Bacterial Wilt. African Crop Science Journal, 16, 89-95.

[14] Karamura, E., Osiru, M., Blomme, G., Lusty, C. and Claudine, P. (2005) Containing Banana Xanthomonas Wilt. Proceedings of the Workshop, Kampala, 14-18 February 2005, 4-9.

[15] Joint FAO/ECE/ILO (2003) Raising Awareness of Forestry, Joint FAO/ECE/ILO Committee on Forest Technology, Management and Training (Monograph). Geneva. http://www.unece.org/fileadmin/DAM/timber/docs/publications-other/raising-awareness.pdf

[16] USAID (2014) Training Manual on Community Participation and Social mobilization in Basic Education. Dhaka Ahsania Mission, UNISCO, Dhaka. http://unesdoc.unesco.org/images/0012/001252/125292e.pdf

[17] Abebe, T. (2005) Diversity in Homegarden Agroforestry Systems of Southern Ethiopia. PhD Thesis, Presented to School of Graduate Studies, Hawassa University, Awassa, 31-60.

[18] Johnson, R.B. and Onwuegbuzie, J.A. (2004) Mixed Methods Research: A Research Paradigm Whose Time Has Come. Educational Researcher, 33, 14-26. http://dx.doi.org/10.3102/0013189X033007014

[19] Wolde, M., Ayalew, A. and Chala, A. (2016) Assessment of Bacterial Wilt (Xanthomonas campestris pv. musacearum) of Enset in Southern Ethiopia. African Journal of Agricultural Research, 11, 1724-1733. http://dx.doi.org/10.5897/AJAR2015.9959

[20] Hunduma, T., Sadessa, K., Hilu, E. and Oli, M. (2015) Evaluation of Enset Clones Resistance against Enset Bacterial Wilt Disease (Xanthomonas campestris pv. musacearum). Journal of Veterinary Science \& Technology, 6, 232.

[21] Shumbulo, A., Gecho, Y. and Tora, M. (2012) Diversity, Challenges and Potentials of Enset (Ensete ventricosum) Production: In Case of Offa Woreda, Wolaita Zone, Southern Ethiopia. Food Science \& Quality Management, 7, 24-31.

[22] McKnight CCRP (2013) Integrated Management of Bacterial Wilt of Enset (Ensete ventricosum (Welw.) Cheesman) Caused by Xanthomonas campestris pv. musacearum in Ethiopia. Enset Bacterial, Enset Bacterial Wilt Annual Report 11-283.

http://ccrp.org/sites/default/files/11-283_enset_year_2_consolidated_report_2013.pdf

[23] Röling, N. and Van de Fliert, E. (1994) Transforming Extension for Sustainable Agriculture. The Case of Integrated Pest Management in Rice in Indonesia. Agriculture and Human Values, 11, 96-108. http://dx.doi.org/10.1007/BF01530451

[24] Torrez, R., Tenorio, J., Valencia, C., Orrego, R., Ortiz, O., Nelson, R. and Thiele, G. (1999) Implementing IPM for Late Blight in the Andes. Impact on a Changing World, CIP Program Report 1997-1998, 91-99.

[25] Karamura, E., Turyagyenda, L., Tinzaara, W., Blomme, G., Molina, A. and Markham, R. (2008) Xanthomonas Wilt of Bananas in East and Central Africa. Diagnostic and Management, Guide Bioversity International Uganda. http://banananetworksorg/barnesa/files/2012/11/Diagnostic-and-Managementguide-toBX W.Pdf 
Submit or recommend next manuscript to SCIRP and we will provide best service for you:

Accepting pre-submission inquiries through Email, Facebook, LinkedIn, Twitter, etc. A wide selection of journals (inclusive of 9 subjects, more than 200 journals)

Providing 24-hour high-quality service

User-friendly online submission system

Fair and swift peer-review system

Efficient typesetting and proofreading procedure

Display of the result of downloads and visits, as well as the number of cited articles

Maximum dissemination of your research work

Submit your manuscript at: http://papersubmission.scirp.org/ 